\title{
Social Media and Fake News in the Post-Truth Era: The Manipulation of Politics in the Election Process*
}

\author{
TURGAY YERLIKAYA* and SECA TOKER ASLAN ${ }^{* *}$ \\ * Istanbul University, Turkey \\ ORCID No: 0000-0002-6134-5788 \\ ** Istanbul University, Turkey \\ ORCID No: 0000-0002-0126-8848
}

\begin{abstract}
This article focuses on how virtual social networks affect socio-political life. The main theme of the article is how social networks such as Facebook and Twitter can direct voters' electoral preferences, especially during election time, through the dissemination of manipulative content and fake news. The use of social media, which was initially thought to have a positive effect on democratization, has been extensively discussed in recent years as threat to democracy. Examples from the 2016 U.S. presidential elections, France, Brexit, Germany, the UK and Turkey will be used to illustrate the risks that social networks pose to democracy, especially during election periods.
\end{abstract}

Keywords: Social media, Fake news, Post-truth, Elections, Manipulation 


\section{Introduction}

he social media platforms that have emerged within the scope of new technologies, and which are new configurations of modern technology and the internet, have led social and political debates to gain new dimensions. The fact that social media notably influenced the revolution/counter-revolution movements that started in December 2010 in Tunisia, and later in Egypt and Syria increased interest in these areas. Internet channels, whose effects were tested on social movements, have now become an indispensable part of social life and have affected politics deeply.

Following these developments, there was an expectation that the emergence of second-generation websites and the dynamic structure of Web 2.0 -the second stage of development of the Internet, characterized especially by the change from static web pages to dynamic or user-generated content and the growth of social media- would strengthen the tendency towards democratization. New forms of Web 2.0 such as Facebook, Twitter and Skype where the individual is effective and where there is an acceptance that reciprocity is possible, strengthened these arguments. In contrast to limited and supervised participation in traditional media, digital media enables individuals to express themselves in an uncontrolled manner and provide a relatively free environment. As a result of the evolution of the Web that was accompanied with rise of online social networks, the conviction that these networks create a freer and more equitable environment has become pervasive. ${ }^{1}$

\section{Theoretical and Methodological Framework}

While new media technologies do contribute to the process of democratization in certain contexts, they can also be used as a means to consolidate the power of authoritarian regimes. There are various discussions in the literature about the impact of internet technologies and social media on processes in democratic and non-democratic countries. Within the context of these debates, there are optimistic approaches that affirm the role of social media on democracy, and those that have a more skeptical point of view. ${ }^{2}$ Optimist approaches suggest that communication technologies have positive effects on democratization and participatory culture, while skeptical approaches draw attention to the use of these technologies in service of authoritarianism, radicalization, manipulation, and surveillance. The question as to whether social media networks affect the electorate during election times and whether they have become a threat to democracy will be approached in this article from a skeptical perspective in order to answer the following questions: Is social media a tool of emancipation or is it a threat? Does, or can, social media affect people during election periods? When assessing social media tools in relation 
to elections, what kinds of negative effects do they have?

The argument that social media tools deeply affect politics and social life first appeared in 2010 after the Arab revolutions that began in Tunisia and spread to Egypt and Syria. ${ }^{3}$ According to Manuel Castells, who openly highlights the relationship between social mobilization and technology, new media tools were used extensively during the Arab revolts. ${ }^{4}$ Furthermore Philip Howard contends that the use of technologies opens up channels that will strengthen democracy, expand civil society and contribute to the democratization of the state. ${ }^{5}$ It was presumed that democratic regimes would replace authoritarian ones with the dissemination of access to information technologies. Contrariwise, the idea that internet platforms have strengthened democracy has been subject to important criticism, especially in recent years.

The claim that new internet technologies and digitalization have become an element of social movements and that they impact socio-political moments has been criticized from many different angles. Many have argued that the structural changes introduced by new media technologies have been misused and have eventually turned into threats against democracy. For them, the Internet and social media are among the biggest threats to states and individuals since they have millions of users in many countries and billions around the world. Instances of fake social media accounts ${ }^{6}$ stirring up social chaos in a country and disseminating content that manipulates the public against governments, elections, or other groups were observed in the 2016 U.S. presidential election, the Brexit referendum, and elections in France, Germany and Turkey. In his book The Net Delusion: The Dark Side of Internet Freedom, Evgeny Morozov strongly criticizes the thesis that social media contributes to democratization and that it helps topple authoritarian regimes. Morozov argues that the internet does not have such power to democratize countries and he describes people who attribute such power to the Internet as cyber-utopics. In contrast, Morozov cites state and non-state actors' use of social media as tools to manipulate social and political life, and he therefore argues that it is a threat to democracy. Taking Morozov's critical and skeptical approach as a starting point, this article will argue that internet technologies are a threat to democracy.

As Morozov points out, social media platforms can be used intensively for manipulation purposes by actors who threaten democracy. Particularly, farright and populist actors that have been on the rise recently use social media to influence and manipulate the masses. ${ }^{7}$ The fact that social media is free 
The claim that new internet technologies and digitalization have become an element of social movements and that they impact socio-political moments has been criticized from many different angles from control and exempt from legal and economic constraints makes it more attractive for populist and far-right figures. ${ }^{8}$ Communication mediums are considered essential for the development of democracy, although they actually prevent the development of democracy and make it easier for extreme movements to find a place. Drawing on Morozov's perspective this study aims to analyze images which are used to manipulate the masses during election times and fake news on print and online media networks. Examples of the use of social media as a tool to threaten democracy from different contexts will be shown. The reason for highlighting Morozov's critical perspective is to reveal how internet environments are used by illicit actors and how elections are manipulated through social media. Examples from different cases in the selected countries will exemplify how internet environments that are expected to spread information and contribute to democratization have evolved to become anti-democratic. Trump's support in the presidential elections and anti-Clinton fake news clearly indicates this evolution. Similarly, anti-Macron fake content produced in favor of Marine Le Pen in France and anti-refugee posts in Turkey show the threatening aspects of these environments. In conclusion, the fact that the far-right and extreme movements in Germany have been successful in the elections and the use of social media tools by far right groups in Germany in addition to that the Uk during the Brexit processs in England give credence to Morozov's skeptism/criticism.

\section{Fake News and the Post-Truth Era in World Politics}

In the early 2000s, the growth of online news prompted a new set of concerns, among them is that an excessive diversity of viewpoints would make it easier for like-minded citizens to form "echo chambers" or "filter bubbles" where they would be insulated from contrary perspectives and meaningful interactions with people of different beliefs. ${ }^{9}$ The algorithms and techniques used in the production of fake news are directly effective in manipulating individuals and are effective in social and ideological polarization. ${ }^{10}$

The terminology "fake news" entered the literature after the 2016 U.S. presidential elections and has been defined as "distorted signals uncorrelated with truth." In a broader sense, fake news has been defined as news articles that are intentionally and verifiably false, and that could mislead readers. ${ }^{11}$ In this way, fake news is different from terms such as disinformation and misinformation, 


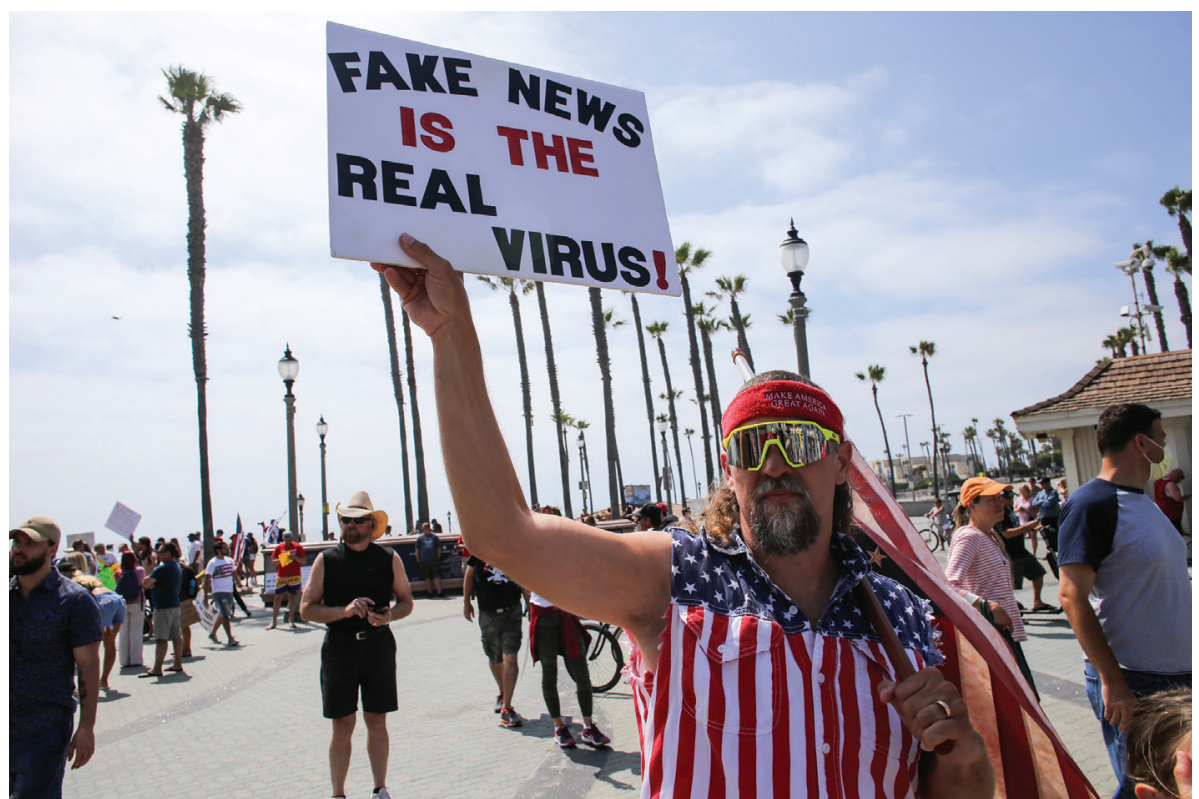

which have also been addressed in the literature. While misinformation has been defined as providing wrong information unintentionally, disinformation is the act of intentionally distorting information. Having more connotations and wider use in everyday life, fake news has been labelled as demonizing by traditional news organizations. ${ }^{12}$ In this sense, by distorting social reality and by being utilized intensely fake news strengthens the claim that we have entered a "post-truth" period in which the truth has lost its value. ${ }^{13}$ The posttruth world is one in which perceptions are more important than truth, and an era in which all sorts of manipulations and fake content can be directed to masses of people with ease.

Produced with ideological and economic foundations, fake news has had demonstrable effects on important events in world politics over the past three years. The UK's Brexit period and the election of Donald Trump in the U.S. were years in which fake news hit its peak. ${ }^{14}$ With the recent rise of digitalization and the increase in new media environments, there have been increasing arguments that fake news is effective in influencing politics. ${ }^{15}$ In fact, it has even been argued that if it were not for fake news, Trump would not have been elected. ${ }^{16}$ The 2017 presidential elections in France and the general elections in Kenya were also strongly affected by fake news content on Facebook and other digital internet platforms. ${ }^{17}$

In light of all these arguments, claims that fake content produced on internet-based platforms affects political preferences and elections have gained
A protester holds a poster reading "Fake News Is The Real Virus" during a demonstration in the U.S. Huntington Beach, California, on May 9, 2020. STANTON SHARPE / SOPA Images / LightRocket via Getty Images 
ground. Through the examples used in this article, it will become clear how world politics is directed through social media and the extent to which democracy has been destroyed or harmed by social media use.

\section{Social Media: A Tool of Freedom or Domination?}

The belief that the innovations introduced by internet technologies would contribute to democratic processes and support democratization has emerged in the literature as a dominant approach. It has been argued that with these new technologies, the obstacles facing more liberal and libertarian societies would be removed and the principle of transparency would prevail. It was believed that internet technologies, seen as a tool of transformation and change, could provide societies with opportunities for more autonomy and democracy in the $21^{\text {st }}$ century. ${ }^{18}$ It was predicted that due to greater social connectivity, voters across the world would unite with other voters in different countries in order to form a global political entity, which had never existed before, and therefore the internet would be used more effectively. ${ }^{19}$ Arguments that stand out within the optimist approach include those claiming that new media and social networks would raise awareness in society and contribute to democratic processes by facilitating organizing activities. In contrast, more skeptical and critical theorists have argued that state and non-state actors use social media as tools to manipulate social and political life and therefore social media is a threat to democracy. ${ }^{20}$ Examples supporting this argument include the intervention in the 2016 U.S. presidential elections through social networks and the use of new media tools in Russia and China with an aim to strengthen their authority.

Figure 1: Social and Political Events where Social Media Has Been Effective

\begin{tabular}{ll|}
\hline - Zapatista \\
\hline Iran Green Movement \\
\hline 2011 & - Occupy Wall Street \\
\hline 2018 & - Brexit Presidential Elections \\
\hline
\end{tabular}


It is possible to divide the impact that social networks have on socio-political life roughly into two periods through case studies of critical importance. While in the first period the Internet was used as a platform to express discontent with existing regimes (for instance Zapatista, the Iran Green Movement, the Arab spring, and Occupy movements), in the second phase the Internet became used as a platform for manipulation, and thus as a tool that threatens democracy. As can be seen from the chart below, the Internet and internet-based technologies can be used for different purposes.

According to a study conducted in 2008, the spread of information and communication technologies in Bahrain, Iran, Jordan, Kuwait, Lebanon, Oman, Qatar, Saudi Arabia, and the United Arab Emirates has had a positive effect on boosting democracy and freedom. In addition to this, it has been found to have had a positive effect on the closure of digital gaps in the region. ${ }^{21}$

When considering events in which social media has been effective in terms of influencing socio-politics, observed as the pioneering wave of social movements, it is well known that internet technologies were used in the Zapatista movement. Adopting the horizontal network organization model, the internet was an effective tool in enabling the movement to spread beyond Mexico. ${ }^{22}$ Similarly, the Arab spring ${ }^{23}$ and the Wall Street protests that arose in response to neo-liberal economic problems are also examples of the effective use of social networks.

With the social changes that came with easy access to information technologies, it was thought that democratic regimes would replace authoritarian ones. ${ }^{24}$ Among democratic regimes, there was an assumption that solutions to the problems that emerge from the clogging of democratic channels would directly lead to representative democracy being replaced by participatory democracy. However, since the number of social media users across the world has reached billions, internet and social media are also being used in the hands of political and social actors to threaten democratic space. In fact, examples such as the 2016 U.S. presidential elections (the Cambridge Analytica scandal), the elections in France and Turkey, the Brexit and other referendums illustrate that manipulation and other anti-democratic interventions have been pursued through the Internet. The instrumentalization of social media is not limited to interventions in democratic countries alone. In countries such as Russia and China, which can be described as systems of "networked author- 
itarianism," social networks are used for the monitoring and surveillance of society. More, political and social life is controlled with the help of internet technologies. ${ }^{25}$

\section{Findings: Social Network-Based Manipulations during Election Periods}

Today, the use of social media tools, which have important effects in shaping political processes, have become widely used for disinformation and propaganda. The conceptualization of this process, which has become known as "computational propaganda," refers to the manipulation of the public in a desired direction via computer technologies. ${ }^{26}$ The instrumentalization of social media tools by both state and non-state actors in the service of propaganda and manipulation poses serious risks for democracy.

Social network-based manipulation efforts, which manifest themselves in three stages, begin with the opening of a fake website that is similar to mainstream media websites in terms of visuals and design. In the second phase, political bots and trawl accounts share the manipulative and fake content produced on the website in question, which enables them to reach a wider audience. In the final stage, the content produced for manipulation is brought to the agenda of online social networks and mainstream media, which allows it to become discussed and further expands the scope of manipulation by attracting the attention of large masses.

It has now become very common to spread fake news and to manipulate voters with fake accounts during election periods. Distorting the personal information of candidates in elections and the character assassination of politicians through false information are also used as an effective method. Another manipulation technique is the sharing of personalized content that will trigger voters emotionally and change their political decisions by conducting voter profile studies. With the advances in artificial intelligence technology, it has become possible to manipulate search results according to the individual. After acknowledging the extent to which the behavior of voters can be affected by character analysis, all actors who want to have influence in the political field have intensified their efforts to manipulate voting behavior accordingly.

For instance, the investigation conducted against the myPersonality app, which belongs to Cambridge University and operates on Facebook, stated that the application may have collected the data of 6 million users. This is important in illustrating the extent of the threat posed. Another example of significant relevance is the application initiated by David Stillwell in 2007 which was supported by Cambridge university. The application collected 
information about the profiles of millions of U.S. citizens. In addition, the fact that the UK-based Cambridge Analytica gathered profile information about the electorate on Facebook and intervened in the 2016 U.S. presidential elections illustrates the extent

Another manipulation strategy that draws attention and was used during the U.S. presidential elections is character suicide to which democracy is under threat.

Alongside the presidential elections in the U.S., the Brexit referendum, the presidential elections in France and the June 24 presidential elections in Turkey also emerge as important cases that depict the extent of intervention and disinformation in democratic countries through social media manipulation.

\section{Fake News and Social Media Manipulations around the Globe}

\section{Fake News in the U.S. Presidential Elections}

Following Trump's victory over Clinton in the 2016 U.S. presidential elections, allegations of electoral fraud arose. Subsequently, the Cambridge Analytica scandal erupted, which strongly illustrated the extent to which social networks are used as tools of manipulation. Following this incident, the fact that Facebook announced that the advertisements published in the U.S. between 2015 and 2017 were made by a Russian internet research agency revealed the seriousness of the allegations. According to various claims, social media networks such as Facebook, Twitter and Instagram were used by Russia with the aim of manipulation, and the presidential election process and election results were influenced with use of fake accounts. ${ }^{27}$

The allegations that Russia manipulated the 2016 presidential elections through state-supported news channels and other third parties, and by using social media troll accounts in exchange for money are still being debated in the public sphere. The fact that the U.S. judiciary has started investigations into some of the persons and institutions that were accused of manipulating the elections shows the seriousness of the issue at stake. ${ }^{28}$ The fact that the manipulations alleged to be of Russian origin have become more frequent in recent times ${ }^{29}$ and that some EU member states have placed restrictions on Russian news agencies also proves the severity of the situation.

A study describing how fake news peaked during the 2016 U.S. presidential election showed the ways in which the conspiracy theories that emerged in the public sphere three months before the election, fake news and false information are effective in social networks. So much so that the rhetoric directed at Obama in order to weaken the Democratic Party candidates, which targeted the country's values and which consisted of news about immigrants, reached 
2.2 million people on Facebook respectively in the three months before the election.

Figure 2: Interaction with Fake News in the U.S. in 2016 (Facebook Interactions in thousands)

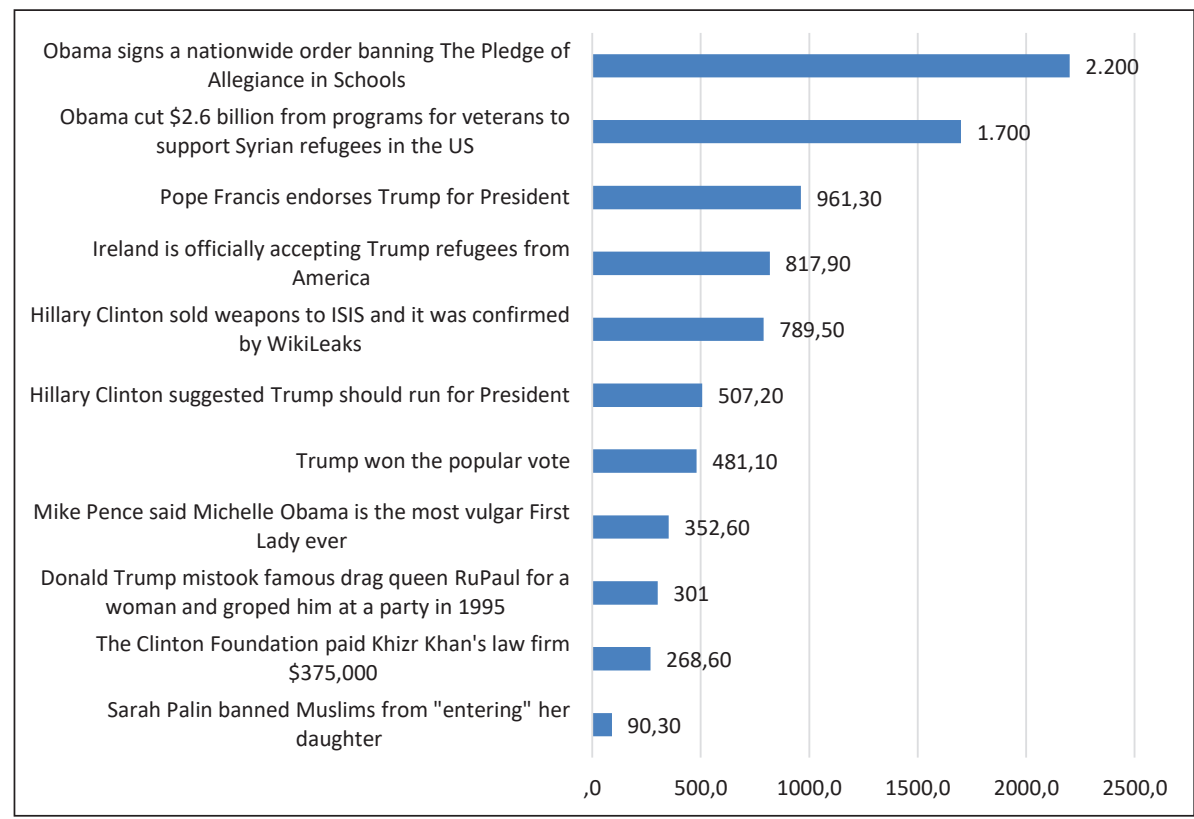

Source: Statista ${ }^{30}$

The most striking example of the fake news that erupted during the presidential elections was the news that the Pope had supported and approved Trump's candidacy. Following the news that was made about Obama, the fake news about the Pope was shared 961,000 times (Table 2). The fact that fake news gets shared so much and reaches millions of people in the U.S. supports the thesis that the manipulations made over social networks have immense influence.

Another manipulation strategy that draws attention and was used during the U.S. presidential elections is character suicide. One of the strategies involved in this type of manipulation was to share humiliating information about Hilary Clinton on social networks and to make other candidates such as Ted Cruz and Marco Rubio look bad in comparison to Trump, in order to ensure that he was the most prominent candidate. The news fabricated with this aim typically supported Trump. Fake news claiming that Hillary Clinton was too ill to perform the duties required of a president was supported by pictures on social media. This contributed to changing the mood of the election race in favor of Trump.

In addition to news about Clinton being ill, others news such as Clinton selling arms to ISIS and that she was involved in the Pizzagate scandal were also 
discussed during the election period. Republican presidential candidate Ted Cruz was the subject of similar news constructed during the race and intended to keep him behind his opponents. During the race, it was claimed that Ted Cruz's father was involved in the Kennedy assassination (Image 1). These fabricated news stories drew immense attention and were heavily debated on social networks. Following Trump's victory in the primary in Indiana, and following Cruz's withdrawal from the race, Trump was confirmed as the republican candidate. This strengthens the argument that the manipulations worked.

Image 1: Fake News about Ted Cruz's Father.

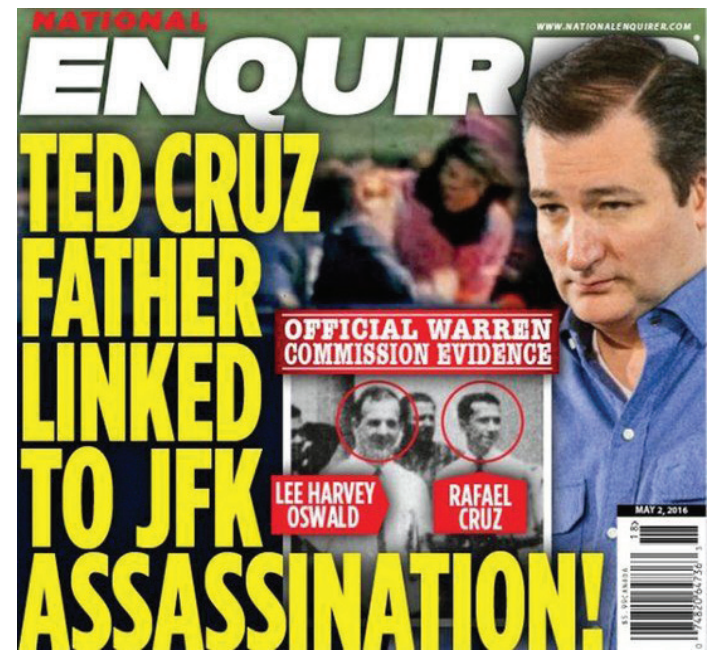

Source: The National Enquirer

\section{Fake News in the 2017 French Presidential Election}

Another example that illustrates how social media was instrumentalized as a tool of manipulation is the French presidential election of 2017. Arguments that began with the claim that Russia was meddling with the elections to bring about a specific outcome brought fake news to the forefront. When the allegations are examined, it is seen that a few days before the elections, fake news aimed at obtaining a desired result circulated through social media providing a speculative flow of information about the election results. The manipulations were generally made against Macron and in favor of far-right candidates. The fake news stories became an important agenda item not only in France but also across the world.

Looking at the process in France, among frequently used manipulation methods were distorting the results of surveys, the character assassination of candidates and the use of deliberate falsehoods to promote far-right anti-immigration positions were used. 
Image 2 provides an example of the institutionalization of anti-immigration policies. Bernard Monot claims, "The state has created a card that gives refugees 40 euros a day." At the end of this lie, it states, "With Marine Le Pen and National Front, French people will be prioritized.”

Image 2: Fake News in France Supporting Right-Wing Election Position.
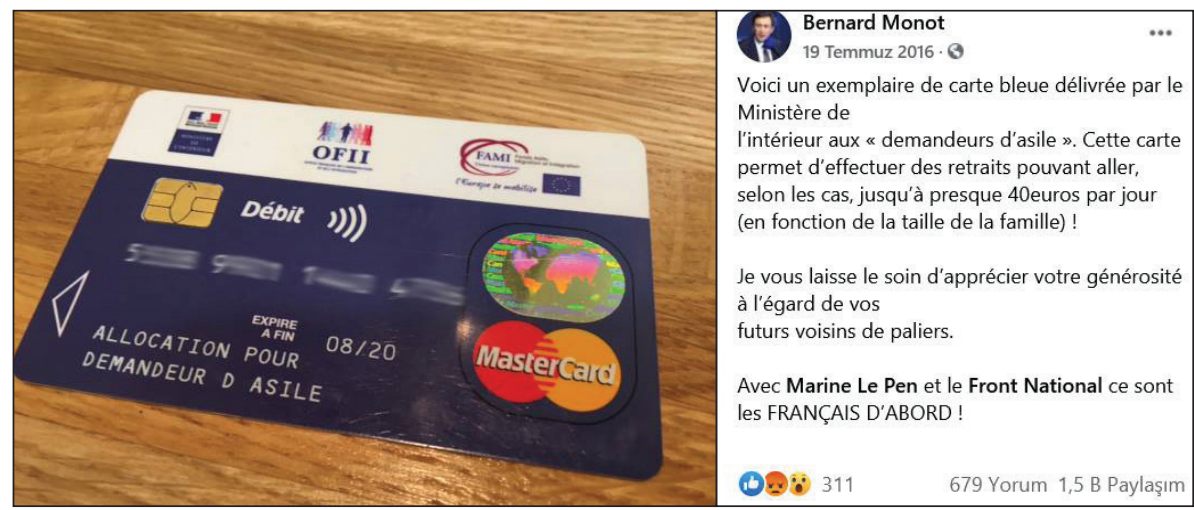

Source: Facebook

Further, a particular image conveying the message that the elections would result in the victory of National Front leader Marine Le Pen was given. Indeed, intervention in surveys and the sharing of unrealistic survey results arose as the most striking manipulation attempts during the election. For example, a poll shared by a web site just before the elections showed that Le Pen would win the first round of elections with 28.1 percent of the vote in the first round. Another poll that was shared just before the elections claimed that the farright candidate François Asselineau would win 56.91 percent of the vote in the first round. Another poll depicted Jean-Luc Melenchon winning the first round. ${ }^{31}$ Manipulative surveys serve the purpose of directing the preferences of the public in order to bring the desired candidate to the forefront and create the perception that other candidates do not have a chance to win the race.

Another variant of social media manipulations favoring Le Pen may be seen in the disinformation and attrition reports on candidates opposing Le Pen. For example, bots circulated information that Macron had an offshore account and that he was illegally using this account. This false allegation shaped public opinion on Macron. These manipulations, aimed at preventing Macron from winning the elections, were not only limited to false surveys; they also adopted a strategy including disinformation and attrition campaigns. The fact that Facebook suspended around 30,000 automatic accounts during the election period on the grounds that they were circulating disinformation regarding political events illustrates the prevalence of manipulations made via social networks. ${ }^{32}$ Following Macron's victory after the elections, a draft law that sought 
to prevent fake news and social media manipulations passed through the senate as a result of great efforts. This reveals France's seriousness in its struggle against social network-based manipulations.

\section{Fake News in the UK}

Manipulations through social media were also the case in the Brexit referendum in the UK. Fake news and disinformation produced on social media throughout the country have recently been officially declared an important threat to democracy. A report by the British Parliament found out that social media platforms were intensively used to influence the prejudices and fears of people and to influence voting preferences. ${ }^{33}$ Calls such as "Our democracy is at risk and we need to take action on this" were made in the parliament, and immediate action was urged in order to prevent manipulations.

Especially due to the fact that the electorate was highly affected during the Brexit referendum, the manipulations carried out over the internet were interpreted as a crisis of democracy. ${ }^{34}$ During the Brexit process, the Leave Group (whose members wanted to leave the European Union) actively used social media and manipulated people with fake news. Drivers of this campaign took advantage of the rising populist wave across the world and created content about the economy and immigration. Adopting an agenda-setting strategy, these groups also created fake news about Turkey and Turks during this period. One story claimed that twelve million Turks were going to come to the UK and change the demographics of the country.

When it became clear that a lot of manipulations were happening over Facebook during the Brexit era, the government sought to prevent this. An investigation into Facebook after its alleged misconduct in the Brexit referendum through Cambridge Analytica found that Facebook had failed to provide correct information and that Facebook managers had refrained from answering the questions of the commission in parliament. The report highlighted the dimension of regulations to be made concerning social networks, and argued that introducing new taxes and establishing legal regulations for companies operating in a technical context is vital to maintaining democratic standards.

\section{Social Media Manipulation in Germany}

Germany is similarly sensitive about social media manipulation and has recently put some legal regulations in place. The country has been among the 
Due to the recent manipulation allegations and hoaxes discussed in Turkey, especially during election times, Turkey needs to be a pioneer in this regard and needs to take certain steps to dispose of the threat emanating from such events

top countries where the subject of manipulation has been thoroughly discussed. The debate that political life was being directed through social networks and that this manipulation was intended to create a particular public opinion during the 2017 elections came to the forefront of Germany's agenda. A 2017 study examining the extent of virtual manipulations during the federal elections found that there were three aspects of manipulation: fake news, social bots, and foreign interference. ${ }^{35}$ The report focused on how this manipulation was handled in Germany. The report, which was prepared with the use of mass data, stated that the right-wing Alternative for Germany (AfD) party dominated social media during the election process and that its election success was related to the party's effective use of social media. As a matter of fact, it became clear that there were active bot accounts on social media working in favor of AfD. The extent to which these accounts were active and the role they played was also examined. Germany is an important example in depicting how far-right and racist ideas find place on social media. The fact that a far-right party with a racist ideology has entered the Bundestag ${ }^{36}$ for the first time since WWII illustrates the extent to which social networks pose a threat to democracy.

The use of social media for manipulative goals during election periods is not only limited to the U.S. and Europe. Recent studies conducted on this issue illustrate the extent to which fake news and other forms of online manipulation can threaten democracies worldwide. In addition to governments, the fact that social media has now become dominated by other actors has become an increasing reality. It has now become inevitable for governments to take action in this policy area. ${ }^{37}$

\section{The Example of Turkey}

Manipulation made through social media, especially during critical times such as elections, is not a new phenomenon for Turkey. In addition to the allegations that Russia had intervened in the U.S. presidential elections, there are similarities between arguments that the same was attempted in Argentina, India, and the UK through Cambridge Analytica and the recent manipulation attempts in Turkey. The 2013 Gezi Park Protests, June 7 and November 1, 2015 elections and the April 16, 2017 referendum are some of the cases that strongly depict the kind of social media operations that were designed in Turkey in order to sway the public opinion in one direction. The main aim 
of these manipulation attempts was to force people to act on emotion. In this sense, the most prominent methods used was character assassination of politicians, pursuing racist activities in order to put pressure on a group of people in society, and spreading false content that extended the country's economic problems on a different dimension in order to create fear and anxiety among the public.

When looked at the different kind of forms that these attempts took place, in addition to manipulation, other strategies such as unfounded claims and fake news being circulated were also adopted. The process works as following: First, false content is shared by a bot account. This content is then shared by a high-profile politician, which increases the scope of the content's audience. This makes it easier to construct public opinion in a desired direction. It is a well-known fact that these fake users, otherwise called as bot accounts, use disinformation and provocation methods related to Syrians especially during election periods.

Image 3: The Card Claimed to Help Syrian Refugees. ${ }^{38}$

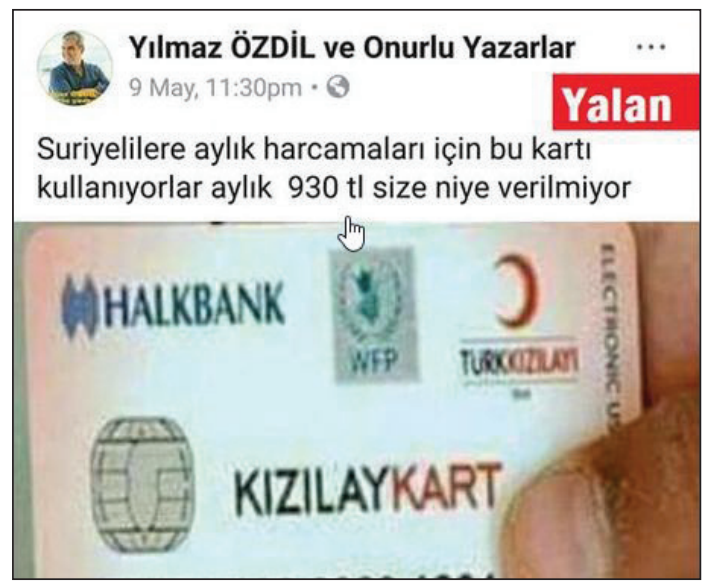

Translation: A card is given to the Syrians for their monthly expenses with a limit of 930 liras. Why is it not given to you?

Source: Twitter

With the mass movement of Syrians into Turkey since 2011, it has become a commonplace to hear some of the following claims about Syrians living in Turkey: Syrians vote illegally; they are granted a university space without sitting the exam required for Turkish students; their telephone bills are paid by the state; they are provided citizenship, an identity card, free housing and a wage. The fact that these unsubstantiated claims circulated through social media are 
accepted by politicians and high-profile figures without any questioning increases tensions among the public. Such claims alienated Syrian refugees prior to the June 24 elections made them a mass target in a clear attempt to influence the election results. ${ }^{39}$ As a matter of fact, the frequent use of fascist discourses that ultimately stimulate nationalist feelings directly targets the current ruling government and are evident in almost every political discourse during election periods.

It is clear that false information and fake news about Syrian refugees intensifies on social media networks during election periods. For example, various manipulations were carried out prior to the referendum held on April 16, 2017, and the general elections that were held on June 24, 2018. The picture shown in Image 3 was used in order to claim that this card was only given to Syrian refugees and that it had a monthly balance of 930 Turkish lira. Similar claims were circulated on social media platforms just before the March 31, 2019 Turkish local elections. However, when the issue is looked at more carefully, it becomes clear that the amount stated by these troll accounts does not reflect reality and that a significant amount of aid provided to Syrian refugees is covered by EU funds. Such false information finds a place in mainstream media from time to time, and its acceptance by some politicians increases its scope of influence. In addition to increasing the number of people that can see these false claims, the fact that they are shared by individuals who have millions of followers on social media also leads to the stories being debated among the public. On many occasions, this causes groups to act in masses. Ultimately, the aim of the fake news circulated on social media networks is to promote nationalism, target the government and put pressure on the economy.

Image 4: Allegations that Anadolu Agency had previously announced the election results. ${ }^{40}$

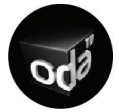

Odatv

@odatv
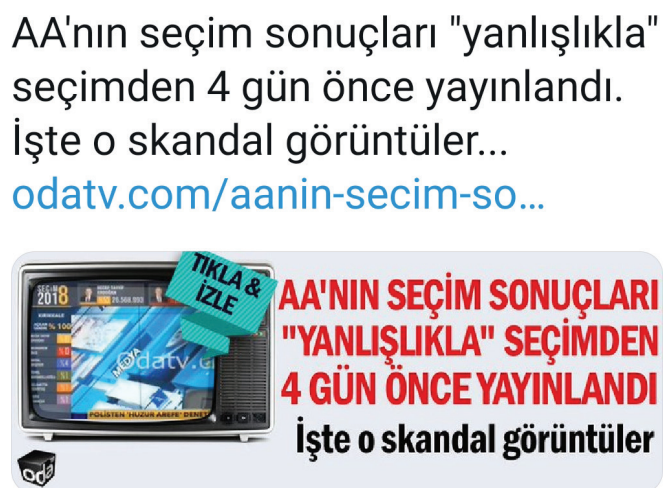

AA'NIN SEÇIM SONUÇLARI "YANLISSLIKLA" SEÇCIMDEN 4 GÜN ONNCE YAYINLANDI İşte 0 skandal görüntüler

Source: Twitter 
As another example, the allegations that the Anadolu Agency "accidently" announced the results four days before the elections (Image 4), which was also supported by the main opposition party, is also important in order to demonstrate the extent of mass manipulation. This issue was first discussed on social media. However, it eventually found its place in the mainstream media and some political figures even called the public to rally and protest on the streets. Due to the recent manipulation allegations and hoaxes discussed in Turkey, especially during election times, Turkey needs to be a pioneer in this regard and needs to take certain steps to dispose of the threat emanating from such events.

\section{Conclusion}

When one looks at the structural changes that have emerged due to new internet technologies, it can be seen that the traditional political codes have changed. The field of politics also shares the same risks. While social networks are expected to contribute to the process of democratization, they should also be considered as the most important threat to democracy today. Governments can make both formal and informal arrangements in order to eliminate the problems arising from the instrumentalization of social networks and internet technologies.

The aim of this article has been to assess the position of new media technologies in the field of politics. It examined the increasing use of internet technologies in contemporary society and illustrated that although these technologies have been believed to contribute to democratization, they in fact have distorted the public sphere and politics in different ways. This article focuses on recent examples of the new phenomenon of fake news and social media manipulations especially during the elections. The limitations of this article include not providing an in-depth analysis of a single case study and the inability to reveal all aspects of fake news. Instead, it presented a comparative overview by using different examples. In-depth and detailed studies are necessary and will further contribute to the literature.

The article discussed attempts to manipulate elections in the U.S., France, Germany, the UK and Turkey and the struggle to use new media tools in the process of elections bearing significant implications for democracy and the role of social media use in democratization. The literature contains both arguments that depict positive examples supporting the merits of social media in the formation of a democratic public space, and negative ones depicting how these technologies threaten democracies. When observed from a chronological point of view, the use of internet technologies in the public sphere began with the Zapatista movement and has extended to our present day. The increasingly professional use of social media for malicious purposes has extended 
into areas such as creating fake news and propaganda in order to influence voter behavior.

While the distinction in history is not clear, this article has divided the use of new media and social networks into two main periods. The 2016 U.S. presidential elections, in which democratic processes were manipulated with new media, was set as the starting date of the second period. The use of fake news and social bots to manipulate public opinion during the 2016 U.S. elections gave has been repeated in all subsequent elections. The first period consists of events that support the optimist view that social media networks contribute positively. However, the second period consists of events that contribute to the negative and skeptical/critical approaches.

\section{Endnotes}

* This article is a shorter and updated version of the report "Seçim Manipülasyonları ve Yalan Haber: 31 Mart 2019 Yerel Seçimleri" published by Seta Foundation.

1. Ronald Deibert, "Authoritarianism Goes Global: Cyberspace Under Siege," Journal of Democracy, Vol. 26, No. 3 (July, 2015), pp. 64-78.

2. Peter Dahlgren, "Social Media and Political Participation Discourse and Deflection," in Christian Fuchs and Marisol Sandoval (eds.), Critique, Social Media, and the Information Society, (New York: Routledge, 2014), pp. 191-202.

3. Linda Herrera, Revolution in the Age of Social Media: The Egyptian Popular Insurrection and Internet, (Verso, 2014), p. 14; Philip N. Howard and Muzammil M. Hussain, Democracy's Fourth Wave?: Digital Media and the Arab Spring, (Oxford: Oxford University Press, 2013).

4. Manuel Castells, Networks of Outrage and Hope: Social Movements in the Internet Age, (Cambridge: Polity Press, 2012).

5. Philip N. Howard, The Digital Origins of Dictatorship and Democracy: Information Technology and Political Islam, (Oxford: Oxford University Press, 2011).

6. Emilio Ferrara, “Disinformation and Social Bot Operations in the Run up to the 2017 French Presidential Election," First Monday, Vol. 22, No. 8.

7. Jacob Groshek and Karolina Koc-Michalska, "Helping Populism Win? Social Media Use, Filter Bubbles, and Support for Populist Presidential Candidates in the 2016 US Election Campaign," Information, Communication and Society, Vol. 20, No. 9, pp. 1389-1407.

8. Claudia Alvares and Peter Dahlgren, "Populism, Extremism and Media: Mapping an Uncertain Terrain," European Journal of Communication, Vol. 31, No. 1 (2016), pp. 46-57.

9. "Filter bubble" refers to the results of the algorithms that dictate what we encounter online. "Echochamber" refers to a metaphoric situation in which a specific kind of opinion and conviction is strengthened and spread through the repetition and the continuous communication among users who share the same kind of thoughts inside a closed system. For the relationship between social media and echo-chambers, see, Majid Khosravinik, "Right Wing Populism in the West: Social Media Discourse and Echo Chambers," Insight Turkey, Vol. 19, No. 3 (Summer 2017), p. 63.

10. Seth Flaxman, et al., "Filter Bubbles, Echo Chambers, and Online News Consumption," Public Opinion Quarterly, Vol. 80, (March 2016), pp. 298-320.

11. Hunt Allcott and Matthew Gentzkow, "Social Media and Fake News in the 2016 Election," Journal of Economic Perspectives, Vol. 31, No. 2 (Spring 2017), p. 213.

12. Edson C. Tandoc Jr, et al., “Defining “Fake News',' Digital Journalism, Vol. 6, No. 2 (2018), p. 141. 
13. For historical context on post-truth, which entered the literature after the 2016 U.S. presidential elections, see Lee C. Mcıntyre, Post-Truth, (Cambridge: MIT Press, 2018).

14. James Ball, Post-Truth: How Bullshit Conquered the World, (London: Biteback Publishing, 2017).

15. Brian McNair, Fake News: Falsehood, Fabrication and Fantasy in Journalism, (London and New York: Routledge), pp. 1-17.

16. Craig Silverman and Jeremy Singer-Vine, "Most Americans Who See Fake News Believe It, New Survey Says," BuzzFeed News, (December 6, 2016).

17. Matt Carlson, "Fake News as an Informational Moral Panic: The Symbolic Deviancy of Social Media During the 2016 US Presidential Election," Information, Communication \& Society, (2018), p. 5.

18. Yochai Benkler, The Wealth of Networks: How Social Production Transforms Market and Freedom, (New Haven: Yale University Press, 2006).

19. Dick Morris, "Direct Democracy and the Internet," Loyola of Los Angeles Law Review, Vol. 34, No. 3 (2001), pp.1033-1054.

20. Evgeny Morozoz, The Net Delusion: The Dark Side of Internet, (Newyork: Public Affairs, 2011).

21. Farid Shirazi, "The Contribution of ICT to Freedom and Democracy: An Empirical Analysis of Archival Data on the Middle East," The Electronic Journal on Information Systems in Developing Countries, Vol. 35 , No. 6 (2008), pp. 1-24.

22. Antonio Negri and Michael Hardt, Çokluk: Imparatorluk Çağında Savaş ve Demokrasi, translated by Barış Yıldırım, (İstanbul: Ayrıntı Yayınları, 2011), p. 101.

23. Zeynep Tüfekçi and Wilson Christopher, "Social Media and the Decision to Participate in Political Protest: Observations From Tahrir Square," Journal of Communication, Vol. 62, No. 2 (September 2012), pp. 363-379.

24. Stating that liberation and social control take place in the same time frame, Deibert and Rohozinski reveal different examples of the use of the intenret for both liberation and control. See, Ronald Deibert and Rafal Rohozinski, "Liberation vs. Control in Cyberspace," Journal of Democracy, Vol. 21, No. 4 (October 2010), pp. 46-47. For a study that focuses on Russia's methods of controlling the internet, see, Sarah Oates, Revolution Stalled: The Political Limits of the Internet in the Post-Soviet Sphere, (Oxford: Oxford University Press, 2013).

25. Mustafa Cem Oğuz, "'"Şebekeleşmiş Otoriteryanizm" ya da Otoriter Rejimlerin Siber Alanla İlişkisi: Rusya ve Çin Üzerine Bir Literatür İncelemesi," Türkiye Iletişim Araştırmaları Dergisi, Vol. 31 (2018), pp. 103-120; Ronald Deibert, Black Code: Surveillance, Privacy and the Dark Side of the Internet, (Toronto: Signal, 2013).

26. Samuel C. Woolley and Philip N. Howard (eds.), Compututaional Propaganda: Political Parties, Politicans, Political Manipulation on Social Media, (New York: Oxford University Press, 2019), p. 3.

27. For allegations that Russia intervened in elections through social networks, particularly in the U.S., UK and many other European countries, see, Samantha Bradshaw and Philip N. Howard. "The Global Organization of Social Media Disinformatıon Campaigns," Journal of International Affairs, Vol. 71, No. 15 (2018), pp. 23-32.

28. Following the allegations in concern, Prosecutor Robert Mueller issued a 37-page indictment and claimed that Russia tried to influence U.S. public opinion through social media during the election period. See, Garrett M. Graff, "A Blockbuster Indictment Details Russia's Attack on US Democracy," Wired, (February 16, 2018); John Swaine, "Mueller Charges 13 Russians with Interfering in US Election to Help Trump," The Guardian, (February 16, 2018).

29. For a pro-U.S. report on the effect that Russian manipulations in Turkey have on the U.S., see, Katherine Castello, "Russia's Use of Media and Information Operations in Turkey: Implications for the United States," RAND Corporation, (2018); For the critique of the report, see , Turgay Yerlikaya, "Bilgi Savaşları ve Uluslararası Müdahaleler," Star Açık Görüş, (October 27, 2018).

30. "Most Popular Fake Election Stories in the United States in 2016, by Facebook Engagement (in Thousands)," Statista, (September 10, 2018), retrieved from https://www.statista.com/statistics/657757/ most-viewed-fake-news-election/. 
31. "French Social Media Awash with Fake News Stories from Sources 'Exposed to Russian Influence' Ahead of Presidential Election," Independent, (April 22, 2017), retrieved May 18, 2019, from https://www. independent.co.uk/news/world/europe/french-voters-deluge-fake-news-stories-facebook-twitter-russian-influence-days-before-election-a7696506.html.

32. "Experts Say Automated Accounts Sharing Fake News Ahead of French Election," Reuters, (April 21, 2017), retrieved May 18, 2019, from https://www.reuters.com/article/us-france-election-socialmedia/ experts-say-automated-accounts-sharing-fake-news-ahead-of-french-election-idUSKBN17M31G.

33. "Social Media Manipulation Putting UK Democracy at Risk: Report," Press TV, (July 28, 2018), retrieved May 20, 2019, from https://www.presstv.com/Detail/2018/07/28/569506/Britain-social-mediafake-news-investigation.

34. "Fake News a Democratic Crisis for UK, MPs Warn," BBC, (July 28, 2018), retrieved May 19, 2019, from https://www.bbc.com/news/technology-44967650 .

35. For more information about the study, see, Juan Carlos Medina Serrano, Simon Hegelich, Mortena Shahrezaye and Oretis Papakyriakopoulos, Social Media Report: The 2017 German Federal Elections, (Munich: TUM University Press, 2018).

36. Erkut Ayvaz, "2017 Almanya Federal Meclis Seçimleri: Sağ Popülizmin Normalleşme Tehlikesi," SETA Analiz, No. 216 (September 2017).

37. "Manipulating Social Media to Undermine Democracy," Freedom House, (December 25, 2017), retrieved May 20, 2019, from freedomhouse.org/report/freedom-net/freedom-net-2017.

38. For more information, see, "Seçimler Yaklaştıkça Alçalıyorlar! Kızılay Kart ile Algı Operasyonu!," Yeni Akit, (Mayıs 12, 2018), retrieved May 20, 2019, from https://www.yeniakit.com.tr/haber/secimler-yaklastikca-alcaliyorlar-kizilay-kart-ile-algi-operasyonu-463542.

39. Turgay Yerlikaya, "Muhalefetin Taşıdığı Potansiyel Faşizm," Star Açık Görüş, (June 3, 2018).

40. "iYi Partili Özdağ: AA'nın Seçim Sonuçları Yanlışlıkla Seçimden Dört Gün Önce Yayınlandı," Sputnik Türkiye, (June 21, 2018), retrieved May 19, 2019, from https://tr.sputniknews.com/turkiye/201806211 033954639-umit-ozdag-aa-secim-sonucu-tvnet/. 